\title{
Ex Vitro Propagation of Rubber Tree (Hevea Brasiliensis) using Stem Cuttings
}

\author{
Anthony Antwi-Wiredu ${ }^{*}$, Samuel Amiteye ${ }^{2}$, Rhoda Gyinae Diawuoh ${ }^{2}$ and \\ George Y. P. Klu ${ }^{3}$
}

\author{
${ }^{1}$ Forestry Research Institute of Ghana, P. O. Box UP 63, KNUST-Kumasi, Ghana. \\ Email: tonysnas@gmail.com \\ ${ }^{2}$ Biotechnology and Nuclear Agriculture Research Institute, Ghana Atomic Energy Commission, P. O. Box LG 80, Legon-Accra. \\ Ghana. \\ Email: samiteye@gmail.com, rgd404@yahoo.com \\ ${ }^{3}$ School of Nuclear and Allied Sciences, University of Ghana, P. O. Box AE1, Atomic Energy-Accra. Ghana. \\ Email: gyp.klu@gmail.com \\ *Author for correspondence
}

\begin{abstract}
Stem cutting propagation preserves the genetic traits and leads to transfer of superior and genetically similar traits of parent plants to progenies. This method is also used to propagate recalcitrant, nonviable and difficult to germinateseeds. Stem cutting in tree species is used to address phenological and intraclonal problems. The use of rubber cuttings as planting material is a feasible option, worthy of investigation. There has been little or no research studies into the usage of Hevea brasiliensis stem cuttings as an alternative vegetative propagation method for an in vivo propagation of rubber tree in Ghana. Propagation of $H$. brasiliensis by stem cutting techniques was used to study alternative procedures for mass production of rubber planting materials. Brown and green rubber stem cuttings of Clone I and Clone II were soaked for 6 hours in 0.0-22.5g/L Naphthalene Acetic Acid (NAA) followed by propagation in a nursery bag filled with nutrient-rich soil. Only the brown stem cuttings of $H$. brasiliensis survived. The percent survival, length of shoots, number of roots as well as length of roots of Clone II was significantly $(P<0.05)$ higher than Clone I. Rubber stem cuttings treated with $15.0 \mathrm{~g} / \mathrm{L} N A A$ significantly $(P<0.05) \quad$ developed higher shoots (83.33\%),number of roots (6.167), length of shoots $(15.38 \mathrm{~cm})$ and length of roots $(6.00 \mathrm{~cm})$ than the remaining treatments. There was significant $(P<0.05)$ effects of $N A A$ and Clone II in sprouting and rooting growth of the brown stem cuttings. Successful in vivo propagation of rubber tree $(H$. brasiliensis)was achieved.

Keywords-Brown and Green, Hevea brasiliensis Clones, Naphthalene Acetic Acid, Sprouting and Rooting Growth, Stem Cuttings.
\end{abstract}

\section{INTRODUCTION}

Rubber seeds are not only very recalcitrant but also of low quality, low vigour potency and low germination frequency. Low quality seed and poor germination rates affect the availability of planting stocks (Palanisamy and Subramanian, 2000). The time taken to raise seedlings of $H$. brasiliensis in nursery before transplantation can be shortened by stem cut nursery techniques. In addition, cost and effort of raising planting materials can be minimised by putting tree parts into mass propagation during the seed-off year or even during peak seasons of rubber trees by utilizing the stems being cut after budding successes (Corpuz, 2013).

Hevea brasiliensiscan be propagated by various methods including in vitro techniques, seedlings from nursery, budding and grafting all of which have their own merits and demerits in production of the plant species. Vegetative propagation facilitates rapid and large scale production of planting materials not only in rubber but also other tree species and can play a key role in tree improvement programmes for multiplication of superior clones or tested plus trees (Palanisamy and Subramanian, 2000).

Intra-clonal heterogeneity emanates from different genetic variations imposed by both the rootstocks and scion-stock of the budded/grafted plantlets. Hevea brasiliensis is currently propagated by grafting and budding techniques. Budding and grafting of different plants or clones cause intra scionrootstock variability. Thus, for genetic stability the budding technique should be avoided. In view of this, stem cuttings and micropropagation are recommended for production of planting materials. A stem cutting inherits all the traits of the donor plant and it is a good substitute for budding and 
grafting. A stem cut inherits all the traits of the tree source (prototype) (Corpuz, 2013).

Propagation by rooted cuttings has been tried as an alternative to overcome the stock/scion effect. Satchuthananthavale, (1973) has reported that cuttings grow better than budding. Furthermore, stem cuttings require limited space. The technique is also rapid, inexpensive and does not require special techniques used in grafting or budding. There is no problem of compatibility with rootstocks or of poor graft unions. The most common treatment to enhance rooting in stem cuttings is the use of growth regulators (Fowler, 2010). These substances enhance cell differentiation, starch hydrolysis, sugar and nutrient mobilization to the basal end of the cuttings resulting in root initiation (Das et al., 1997).

There is rapid root formation and development and higher percentage of roots on cuttings treated with auxins (Leakey, 2004). Of all the growth regulators (auxins, cytokinins, gibberellins, abscisic acids and ethylene), auxins have the greatest effect on root formation in cuttings. Auxins are not only involved in rooting but also enhance stem growth, lateral bud inhibition, abscission of leaves and fruits and activation of cambial cells. Besides, the naturally occurring indole-3-acetic acids (IAA), there are more effective synthetic auxins such as indolebutyric acid-IBA, naphthaleneacetic acid-NAA (Fowler, 2010) which is used in rooting of rubber stem cuttings.

Since juvenile rubber shoots are very sensitive to desiccation and high temperature, they require immediate use of their cuttings for propagation. Rubber is a seasonal tree species which does not produce fruits regularly, thus production of planting materials is seriously hindered.There has been little or no research studies into the application of stem cuttings of Hevea brasiliensis as an alternative vegetative propagation method for anin vivo propagation of rubber tree in Ghana.The ability to successfully regenerate planting materials from Hevea through in vivo locally would go a long way in rubber improvement and not only of rubber trees but also stimulate interest in attempts at in vivo propagation of some tropical woody species in the country.

The use of stem cuttings will resolve the problem associated with the shortage of rubber planting materials usually in the off-season and lead to the large-scale production of rubber propagules affordable to rubber outgrowers.Moreover, production of rubber planting materials via stem cuttings with their own root system could counteract the major setback associated with budding/grafting which is intraclonal variation due to stock-scion interaction.

This study is aimed at using rubber stem cuttings influenced by clonal types, stem types and growth regulator as an alternative to budding and grafting technique for planting material development. Specific objectives are to:

- determine the survival rate of lignified (brown) and non-lignified (green) stem cuttings of rubber as affected by clones and NAA levels;

- determine the sprouting (shoot development) and rooting growth of $H$. brasiliensis stem cuttings as influenced by the clones and the rooting compound;

- determine the survival rate, length of sprouts and length of roots among $H$. brasiliensis stem cuttings as influenced by the clones and the NAA at varying concentrations.

\section{MATERIALS AND METHODS}

\subsection{Collection of Hevea brasiliensisstem cuttings}

Rubber cuttings of two Hevea clones (Clone I and Clone II) were used in this study. They were collected from rubber outgrowers in the Western Region of Ghana.

\subsection{Propagation of Hevea brasiliensis by stem cuttings}

One hundred and twenty (120) lignified (brown) and nonlignified (green) rubber stem cuttings of each of the two Hevea clones (Clone I and Clone II) were prepared from harvested stems. Each cutting was trimmed to a uniform length of $40 \mathrm{~cm}$ with each cutting consisting of 4 or 5 nodes. The basal portions of the cuttings were then immersed in 0.0, $7.5,15.0$ or $22.5 \mathrm{~g} / \mathrm{L}$ NAA for 6 hours and thereafter planted in nursery bags filled with sandy-loam soil mixed with manure in a ratio of 3:1. The experiment was arranged in a $2 \times 4 \times 5$ factorial experiment with three (3) replications. The number of stem cuttings of each clone was determined as (2 clones $\mathrm{x} 4$ treatments $\mathrm{x} 3$ replications $\mathrm{x} 5$ cuttings per treatment $=120$ ).

Stem cuttings were considered potentially sprouted when their buds ruptured or became visible. The number of cuttings that sprouted was counted at 20-day intervals after planting for four times (20,40, 60 and 80 days). The number of cuttings that developed shoots (survival), number of roots and number of shoots were counted. The length of shoots as well as the length of roots measured using a metre rule 80 days after planting.

\subsection{Data analysis}

Data was subjected to analysis of variance (ANOVA) using the Statgraphics ${ }^{\circledR}$ Centurion XVI. Fisher's least significant difference (LSD) procedure was used for the separation of means where appropriate at $5 \%$. 


\section{RESULTS}

\subsection{Effects of clonal types and NAA concentrations on} shoot development

None of the green stem cuttings survived irrespective of the clonal types and the concentrations of NAA suggesting the stem types have an influence on sprouting or shoot development. Contrarily, Hevea brasiliensis brown stem cuttings (Fig. 1) survived irrespective of the clonal types and NAA levels. A higher significant difference was observed in the survival rate (cuttings that did not die), sprouting and rooting potentials between brown and green stem cuttings of Hevea brasiliensis clones. Total number of brown stem cuttings planted $=120$. Number of brown stem sprouted $=87$. This implies that percentage of brown stem cuttings sprouted: $\frac{\mathbf{8 7}}{\mathbf{1 2 0}} \times 100 \%$

Therefore, percentage of $H$. brasiliensis brown stem cuttings sprouted was72.5\%.
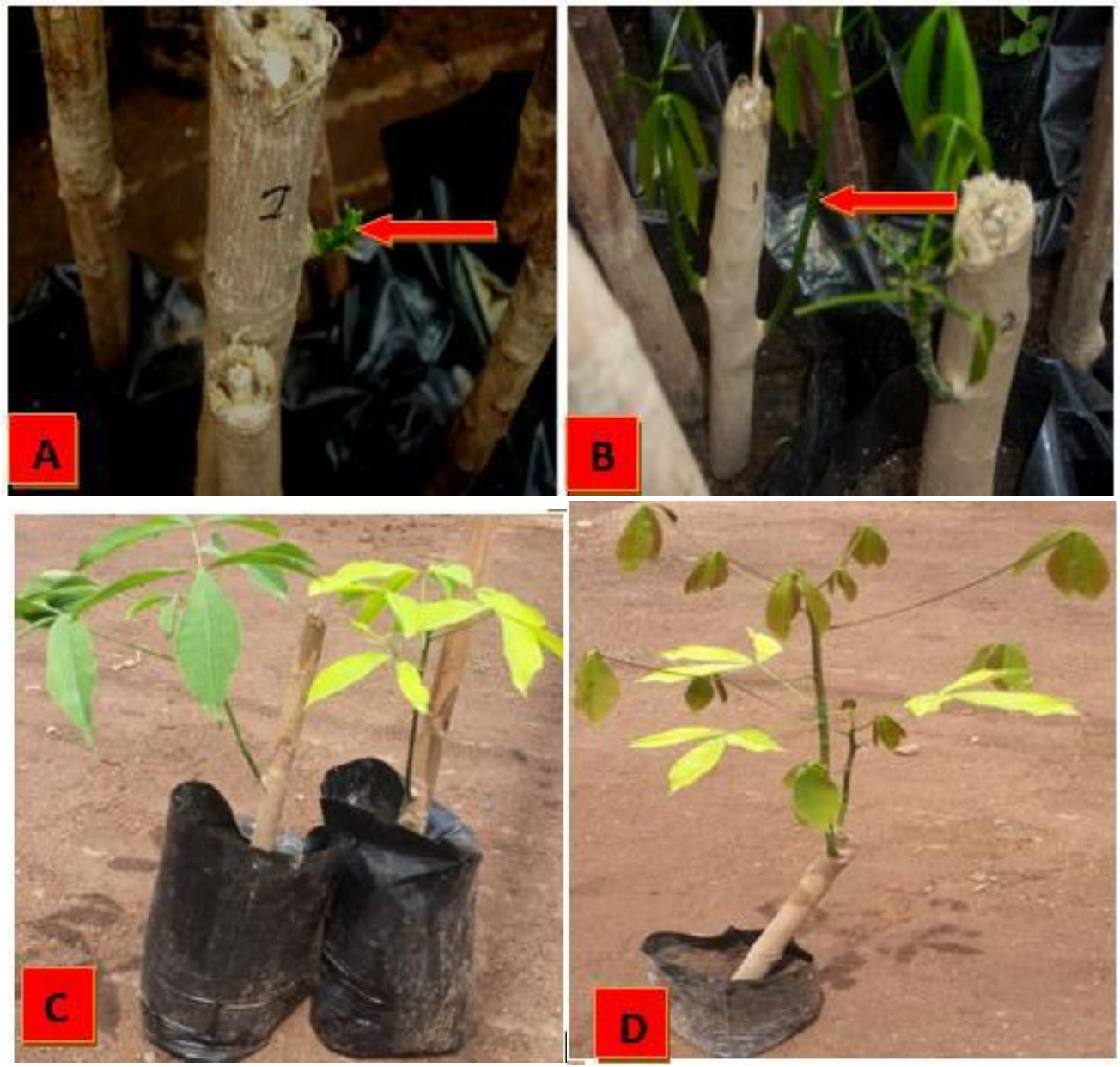

Fig.1: H. brasiliensis brown stem cuttings used for propagation

Fig.2 (A-E): Morphological characteristics, growth and developmental stages of stem cuttings of two H. brasiliensis clones treated with NAA.

A-Stem cutting of $H$. brasiliensis showing shoots 20 days after planting

B- Stem cutting of $H$. brasiliensis showing shoots 40 days after planting

C- Rubber stems cuttings showing well-developed shoots 60 days after planting

D- Rubber stem cuttings showing well-developed shoots 80 days after planting

E-Uprooted rubber stem cuttings with root and shoot systems 
3.2. Effects of types of clone on sprouting growth, survival rate, length of sprouts, number of roots and length of roots of $\boldsymbol{H}$. brasiliensisstem cuttings

Table 1 depicts effect of types of clone on shoot development, survival rate, length of sprouts, length of roots and number of roots of $H$. brasiliensis stem cuttings 80 days after planting (DAP). The clonal types in 20 (Fig. 2A) and 60 (Fig. 2C) days after planting had no significant effects on the sprouting growth of the Hevea brasiliensis stem cuttings between the clones (Table 1). Although, the clonal types on the $40^{\text {th }}$ (Fig. 2B) and $80^{\text {th }}$ (Fig. 2D) days after planting had no significant effect on the sprouting growth of the stem cuttings, Clone II showed higher performance than Clone I (Table 1).
The clonal types, however, showed a significant difference $(\mathrm{P}<0.05)$ in the survivability of the brown stem cuttings (Table 1). Clone II showed a higher mean number of survived stem cuttings representing more than half of the number of brown stem cuttings that survived (Table 1). The survivability of cuttings is very important in the establishment of planting materials since the growth and rooting depend on the ability of the cuttings to survive.

After 80 (Fig. 2D) days of propagation, brown stem cuttings of Clone II of Hevea brasiliensis had a higher survival percentage of $98.333 \%$ as compared to $55.000 \%$ of Clone I. Thus, there was a significant difference $(\mathrm{P}<0.05)$ between Clone I and Clone II (Table 1).

Table.1: Effect of types of clone on the sprouting growth/shoot development, survival rate, length of sprouts, number of roots and length of roots of brown $H$. brasiliensisstem cuttings 80 days after planting (DAP)

\begin{tabular}{|c|c|c|c|c|c|c|c|c|}
\hline \multirow{2}{*}{$\begin{array}{l}\text { TYPE } \\
\text { OF } \\
\text { CLONE } \\
\text { S } \\
\end{array}$} & \multicolumn{4}{|c|}{$\begin{array}{c}\text { NUMBER OF CUTTINGS SPROUTED } \\
\text { DAYS AFTER PLANTING }\end{array}$} & \multirow[b]{2}{*}{$\begin{array}{l}\text { PERCENT } \\
\text { SURVIVAL } \\
(\%)\end{array}$} & \multirow[b]{2}{*}{$\begin{array}{l}\text { SHOOT } \\
\text { LENGTH/C } \\
\text { M }\end{array}$} & \multirow[b]{2}{*}{$\begin{array}{l}\text { ROOT } \\
\text { NUMBER }\end{array}$} & \multirow[b]{2}{*}{$\begin{array}{l}\text { ROOT } \\
\text { LENGTH/C } \\
\text { M }\end{array}$} \\
\hline & 20-DAY & 40-DAY & 60-DAY & 80-DAY & & & & \\
\hline CLONE & $0.500 \pm 0.90$ & $0.500 \pm 0.90$ & $0.667 \pm 0.77$ & $1.333 \pm 0.98$ & $55.000 \pm 33.1$ & & $2.917 \pm 0.99$ & \\
\hline$I$ & $5^{\mathrm{a}}$ & $5^{\mathrm{a}}$ & $8^{\mathrm{a}}$ & $5^{\mathrm{a}}$ & $66^{\mathrm{a}}$ & $6.167 \pm 3.228^{\mathrm{a}}$ & $6^{\mathrm{a}}$ & $4.000 \pm 1.414^{\mathrm{a}}$ \\
\hline $\begin{array}{l}\text { CLONE } \\
\text { II }\end{array}$ & $\begin{array}{l}0.500 \pm 0.52 \\
2^{\mathrm{a}}\end{array}$ & $\begin{array}{l}0.500 \pm 0.52 \\
2^{\mathrm{a}}\end{array}$ & $\begin{array}{l}1.250 \pm 1.05 \\
5^{\mathrm{a}}\end{array}$ & $\begin{array}{l}2.000 \pm 0.85 \\
3^{\mathrm{a}}\end{array}$ & $\begin{array}{l}98.333 \pm 5.77 \\
4^{b}\end{array}$ & $\begin{array}{l}11.950 \pm 7.13 \\
3^{\mathrm{b}}\end{array}$ & $\begin{array}{l}5.000 \pm 2.66 \\
3^{b}\end{array}$ & $5.667 \pm 2.146^{b}$ \\
\hline
\end{tabular}

Means with the same letter superscript are not significantly different $(\mathrm{P} \geq 0.05)$

Regardless of the concentration of NAA, almost all the survived brown stem cuttings showed significant $(\mathrm{P}<0.05)$ length of shoots/sprouts between the two clones of Hevea brasiliensis. With the length of shoots measured after 80 (Fig. 2D) days of propagation, Clone II of the brown stem cuttings performed significantly higher in mean length of $11.950 \mathrm{~cm}$ than that of Clone $I$ in mean length of $6.167 \mathrm{~cm}$ (Table 1). Therefore, this signifies that Clone II brown stem cuttings grow and develop faster in shoot length up to 80 days of planting (Table 1).

Clonal types had a significant difference $(\mathrm{P}<0.05)$ in both the number of roots and the length of roots of the brown stem cuttings. The number of roots developed varied significantly as influenced by the clones of the brown stem cuttings. The Clone II brown stem cuttings statistically were higher in the mean number of roots (5.000) compared with (2.917) in Clone I brown stem cuttings (Table 1).

In the case of the length of roots, Clone II of the brown stem cuttings once again was statistically longer in mean length of $5.667 \mathrm{~cm}$ compared to the $4.000 \mathrm{~cm}$ of the Clone I brown stem cuttings (Table 1).
3.3. Effects of NAA concentrations on sprouting growth, survival rate, length of shoots, length of roots and number of root of $\boldsymbol{H}$. brasiliensisstem cuttings

Table 2 shows the effects of concentration of NAA on shoot development, survival rate, length of sprouts, length of roots and number of roots of $H$. brasiliensis stem cuttings 80 days after planting (DAP). The concentration of NAA did not have significant effects on the sprouting of the brown stem cuttings $20^{\text {th }}, 40^{\text {th }}, 60^{\text {th }}$ and $80^{\text {th }}$ days after planting (Table 2). Similarly, no significant difference $(\mathrm{P} \geq 0.05)$ was observed in all the days after planting among the NAA treatments in the sprouting growth of the brown stem cuttings of $H$. brasiliensis (Table 2).

Though, 15.0g/L NAA was higher (1.000) in sprouting of the brown stem cuttings in both the $20^{\text {th }}$ (Fig. 2A) and $40^{\text {th }}$ (Fig. 2B) days after planting, statistically, it showed no significant difference $(\mathrm{P} \geq 0.05)$ with the other NAA concentrations. At 60 (Fig. 2C) days, both 7.5g/L and $22.5 \mathrm{~g} / \mathrm{L} \mathrm{NAA}$ had similar number of cuttings sprouted (1.333) which were not 
significantly different $(\mathrm{P} \geq 0.05)$ from the remaining treatments (Table 2).

Although at 80 days, no significant difference existed among the treatments, the trend increased with the control treatments and the $7.5 \mathrm{~g} / \mathrm{L}$ NAA showing a higher and equal number of sprouted cuttings of 1.833 . At 80 days after planting, almost all the living cuttings sprouted (Fig. 2D) and at this propagation time, a large number of stem cuttings sprouted (Table 2).

Table.2: Effect of NAA levels applied on the sprouting growth /shoot development, survival rate, length of sprouts, number of roots and length of roots of $H$. brasiliensisstem cuttings 80 days after planting (DAP)

\begin{tabular}{|c|c|c|c|c|c|c|c|c|}
\hline \multirow{2}{*}{$\begin{array}{l}\text { CON } \\
\text { C. OF } \\
\text { NAA } \\
\text { (g/L) }\end{array}$} & \multicolumn{4}{|c|}{$\begin{array}{c}\text { NUMBER OF CUTTINGS SPROUTED } \\
\text { DAYS AFTER PLANTING }\end{array}$} & \multirow[b]{2}{*}{$\begin{array}{l}\text { PERCENT } \\
\text { SURVIVAL } \\
(\%)\end{array}$} & \multirow[b]{2}{*}{$\begin{array}{l}\text { SHOOT } \\
\text { LENGTH/C } \\
\text { M }\end{array}$} & \multirow[b]{2}{*}{$\begin{array}{l}\text { ROOT } \\
\text { NUMBER }\end{array}$} & \multirow[b]{2}{*}{$\begin{array}{l}\text { ROOT } \\
\text { LENGTH/C } \\
\text { M }\end{array}$} \\
\hline & 20-DAY & 40-DAY & 60-DAY & 80-DAY & & & & \\
\hline $\begin{array}{l}\text { Contr } \\
\text { ol }\end{array}$ & $\begin{array}{l}0.333 \pm 0.51 \\
6^{\mathrm{a}}\end{array}$ & $\begin{array}{l}0.333 \pm 0.51 \\
6^{\mathrm{a}}\end{array}$ & $\begin{array}{l}0.500 \pm 0.54 \\
8^{\mathrm{a}}\end{array}$ & $\begin{array}{l}1.833 \pm 1.47 \\
2^{\mathrm{a}}\end{array}$ & $\begin{array}{l}63.333 \pm 42.73 \\
9^{a}\end{array}$ & $3.067 \pm 2.013^{\mathrm{a}}$ & $\begin{array}{l}1.833 \pm 0.75 \\
3^{\mathrm{a}}\end{array}$ & $2.167 \pm 0.408^{\mathrm{a}}$ \\
\hline 7.5 & $\begin{array}{l}0.333 \pm 0.51 \\
6^{\mathrm{a}}\end{array}$ & $\begin{array}{l}0.333 \pm 0.51 \\
6^{\mathrm{a}}\end{array}$ & $\begin{array}{l}1.333 \pm 0.51 \\
6^{\mathrm{a}}\end{array}$ & $\begin{array}{l}1.833 \pm 0.75 \\
3^{a}\end{array}$ & $\begin{array}{l}76.667 \pm 32.04 \\
2^{\mathrm{a}}\end{array}$ & $\begin{array}{l}6.833 \pm 2.406^{\mathrm{a}} \\
\mathrm{b}\end{array}$ & $\begin{array}{l}3.833 \pm 1.16 \\
9^{\mathrm{ab}}\end{array}$ & $5.833 \pm 1.169^{b}$ \\
\hline 15.0 & $\begin{array}{l}1.000 \pm 1.09 \\
5^{a}\end{array}$ & $\begin{array}{l}1.000 \pm 1.09 \\
5^{a}\end{array}$ & $\begin{array}{l}0.667 \pm 0.51 \\
6^{\mathrm{a}}\end{array}$ & $\begin{array}{l}1.333 \pm 0.51 \\
6^{\mathrm{a}}\end{array}$ & $\begin{array}{l}83.333 \pm 32.04 \\
2^{\mathrm{a}}\end{array}$ & $\begin{array}{l}15.383 \pm 6.65 \\
6^{c}\end{array}$ & $\begin{array}{l}6.167 \pm 2.78 \\
7 \mathrm{c}\end{array}$ & $6.000 \pm 1.673^{b}$ \\
\hline 22.5 & $\begin{array}{l}0.333 \pm 0.51 \\
6^{\mathrm{a}}\end{array}$ & $\begin{array}{l}0.333 \pm 0.51 \\
6^{\mathrm{a}}\end{array}$ & $\begin{array}{l}1.333 \pm 1.63 \\
3^{\mathrm{a}}\end{array}$ & $\begin{array}{l}1.667 \pm 1.03 \\
3^{\mathrm{a}}\end{array}$ & $\begin{array}{l}83.333 \pm 23.38 \\
1^{a}\end{array}$ & $\begin{array}{l}10.950 \pm 4.41 \\
8^{\text {bc }}\end{array}$ & $\begin{array}{l}4.000 \pm 1.41 \\
4^{\mathrm{b}}\end{array}$ & $5.333 \pm 1.366^{b}$ \\
\hline
\end{tabular}

Means with the same letter superscript are not significantly different $(\mathrm{P} \geq 0.05)$

The level of NAA concentrations showed no significant difference $(\mathrm{P} \geq 0.05)$ in the survivability (cuttings that did not die) of the brown stem cuttings. The controls are significantly lower in survival $(63.333 \%)$ compared with $76.667 \%, 83.333 \%$ and $83.333 \%$ of $7.5 \mathrm{~g} / \mathrm{L}, 15.0 \mathrm{~g} / \mathrm{L}$ and $22.5 \mathrm{~g} / \mathrm{L}$ NAA respectively (Table 2 ).

The concentration of NAA had effect on length of shoots/sprouts and this effect was highly significant $(\mathrm{P}<0.05)$ (Table 2) suggesting NAA had a significant influence on shoot development. The length of shoots ranged from
$15.383 \mathrm{~cm}$ to $3.067 \mathrm{~cm}$ with $15.0 \mathrm{~g} / \mathrm{L}$ NAA having the highest significant mean length of shoots (Table 2).

Similarly, the concentration of NAA had effect on the root growth of brown stem cuttings and the effect was highly significant $(\mathrm{P}<0.05)$ (Table 2$)$. The effect of NAA on the length of roots varied significantly $(\mathrm{P}<0.05)$ between the controls and the NAA treatments (Table 2). The $15.0 \mathrm{~g} / \mathrm{L}$ NAA significantly had a higher mean number of roots (6.167) and root length $(6.000 \mathrm{~cm})$ compared to the control treatments with number of roots (1.833) and mean length of roots $(2.167 \mathrm{~cm})$ (Table 2$)$. 
3.4. Effects of clonal types and NAA levels on sprouting growth, survival rate, length of sprouts, and number of root and length of roots of $\boldsymbol{H}$. brasiliensis stem cuttings Table 3 depicts the effects of type of clones and level of NAA applied on shoot development, survival rate, length of sprouts, length of roots and number of root of $\mathrm{H}$. brasiliensis brown stem cuttings 80 days after planting (DAP). The interaction between Clone $I$ and NAA levels statistically showed no significance $(\mathrm{P} \geq 0.05)$ in the sprouting of the brown stem cuttings in the number of days after planting (Table 3).

Also, brown stem cuttings showed no significant difference $(\mathrm{P} \geq 0.05)$ in the number of cuttings sprouted in all the days after planting in the interaction between Clone II and NAA levels (Table 3). On the $20^{\text {th }}$ (Fig. 2A) and $40^{\text {th }}$ (Fig. 2B) day after planting, though no significant difference existed between $15 \mathrm{~g} / \mathrm{L}$ NAA and the other treatments, it significantly $(\mathrm{P}<0.05)$ showed high number of sprouted stem cuttings (1.333).

On the $60^{\text {th }}$ (Fig. 2C) and $80^{\text {th }}$ (Fig. 2D) days after planting, $22.5 \mathrm{~g} / \mathrm{L}$ NAA and the control treatments significantly had a high number of sprouted stem cuttings of 2.000 and 2.667 respectively (Table 3 ). It was observed that a few number of cuttings sprouted in the first three data collection days. In both clones, a large number of stem cuttings sprouted on the $80^{\text {th }}$ day after planting (Table 3 ).

Table.3: Effect of types of clone and level of NAA applied on the sprouting growth/shoot development, survival rate, length of sprouts, number of roots and length of roots of $H$. brasiliensis stem cuttings 80 days after planting (DAP)

\begin{tabular}{|c|c|c|c|c|c|c|c|c|c|}
\hline \multirow[b]{2}{*}{$\begin{array}{l}\text { TYPE OF } \\
\text { CLONES }\end{array}$} & \multirow{2}{*}{$\begin{array}{l}\text { CO } \\
\text { NC. } \\
\text { OF } \\
\text { NA } \\
\text { A } \\
\text { (g/ } \\
\text { L) }\end{array}$} & \multicolumn{4}{|c|}{$\begin{array}{c}\text { NUMBER OF CUTTINGS } \\
\text { SPROUTED } \\
\text { DAYS AFTER PLANTING }\end{array}$} & \multirow[b]{2}{*}{$\begin{array}{l}\text { PERCEN } \\
\text { T } \\
\text { SURVIV } \\
\text { AL }(\%)\end{array}$} & \multirow[b]{2}{*}{$\begin{array}{l}\text { SHOO } \\
\text { T } \\
\text { LENGT } \\
\text { H/CM }\end{array}$} & \multirow[b]{2}{*}{$\begin{array}{l}\text { ROOT } \\
\text { NUMB } \\
\text { ER }\end{array}$} & \multirow[b]{2}{*}{$\begin{array}{l}\text { ROOT } \\
\text { LENGT } \\
\text { H/CM }\end{array}$} \\
\hline & & 20-DAY & 40-DAY & 60-DAY & 80-DAY & & & & \\
\hline \multirow[t]{4}{*}{ CLONE I } & 0.0 & $\begin{array}{l}0.333 \pm 0 . \\
577^{\mathrm{ab}}\end{array}$ & $\begin{array}{l}0.333 \pm 0 . \\
577^{\mathrm{ab}}\end{array}$ & $\begin{array}{l}0.333 \pm 0 . \\
577^{\mathrm{ab}}\end{array}$ & $\begin{array}{l}1.000 \pm 1.73 \\
2^{\mathrm{abc}}\end{array}$ & $\begin{array}{l}33.333 \pm 41 \\
.633^{\mathrm{a}}\end{array}$ & $\begin{array}{l}2.633 \pm 2 . \\
715\end{array}$ & $\begin{array}{l}1.667 \pm 0 . \\
577^{\mathrm{a}}\end{array}$ & $\begin{array}{l}2.000 \pm 0 . \\
000^{\mathrm{a}}\end{array}$ \\
\hline & 7.5 & $\begin{array}{l}0.000 \pm 0 . \\
000^{\mathrm{a}}\end{array}$ & $\begin{array}{l}0.000 \pm 0 . \\
000^{\mathrm{a}}\end{array}$ & $\begin{array}{l}1.333 \pm 0 . \\
577^{\text {abcd }}\end{array}$ & $\begin{array}{l}1.667 \pm 0.57 \\
7 \text { bcd }\end{array}$ & $\begin{array}{l}53.333 \pm 30 \\
.551^{\mathrm{ab}}\end{array}$ & $\begin{array}{l}5.333 \pm 2 . \\
454\end{array}$ & $\begin{array}{l}3.333 \pm 0 . \\
577^{\mathrm{bc}}\end{array}$ & $\begin{array}{l}5.000 \pm 1 . \\
000^{\mathrm{bc}}\end{array}$ \\
\hline & 15.0 & $\begin{array}{l}1.333 \pm 1 . \\
528^{\text {abcd }}\end{array}$ & $\begin{array}{l}1.333 \pm 1 \\
528^{\text {abcd }}\end{array}$ & $\begin{array}{l}0.333 \pm 0 . \\
577^{\mathrm{ab}}\end{array}$ & $\begin{array}{l}1.333 \pm 0.57 \\
7^{\text {abcd }}\end{array}$ & $\begin{array}{l}66.667 \pm 41 \\
.633^{\mathrm{abc}}\end{array}$ & $\begin{array}{l}9.567 \pm 1 . \\
701\end{array}$ & $\begin{array}{l}3.667 \pm 0 . \\
577^{\mathrm{cd}}\end{array}$ & $\begin{array}{l}4.667 \pm 0 . \\
577^{\mathrm{b}}\end{array}$ \\
\hline & 22.5 & $\begin{array}{l}0.333 \pm 0 . \\
577^{\mathrm{ab}}\end{array}$ & $\begin{array}{l}0.333 \pm 0 . \\
577^{\mathrm{ab}}\end{array}$ & $\begin{array}{l}0.667 \pm 1 . \\
155^{\mathrm{abc}}\end{array}$ & $\begin{array}{l}1.333 \pm 1.15 \\
5^{\text {abcd }}\end{array}$ & $\begin{array}{l}66.667 \pm 23 \\
.094^{\text {abc }}\end{array}$ & $\begin{array}{l}7.133 \pm 1 . \\
589\end{array}$ & $\begin{array}{l}3.000 \pm 1 . \\
000^{\mathrm{abc}}\end{array}$ & $\begin{array}{l}4.333 \pm 1 . \\
155^{\mathrm{b}}\end{array}$ \\
\hline CLONE II & 0.0 & $\begin{array}{l}0.333 \pm 0 . \\
577^{\mathrm{ab}}\end{array}$ & $\begin{array}{l}0.333 \pm 0 . \\
577^{\mathrm{ab}}\end{array}$ & $\begin{array}{l}0.667 \pm 0 . \\
577^{a b c}\end{array}$ & $\begin{array}{l}2.667 \pm 0.57 \\
7^{d}\end{array}$ & $\begin{array}{l}93.333 \pm 11 \\
.547^{\mathrm{bc}}\end{array}$ & $\begin{array}{l}3.500 \pm 1 \\
479\end{array}$ & $\begin{array}{l}2.000 \pm 1 . \\
000^{\mathrm{ab}}\end{array}$ & $\begin{array}{l}2.333 \pm 0 . \\
577^{\mathrm{a}}\end{array}$ \\
\hline
\end{tabular}




\begin{tabular}{|c|c|c|c|c|c|c|c|c|}
\hline 7.5 & $\begin{array}{l}0.667 \pm 0 . \\
577^{\mathrm{abc}}\end{array}$ & $\begin{array}{l}0.667 \pm 0 \\
577 \mathrm{abc}\end{array}$ & $\begin{array}{l}1.333 \pm 0 \\
577^{\mathrm{abcd}}\end{array}$ & $\begin{array}{l}2.000 \pm 1.00 \\
0^{\text {cd }}\end{array}$ & $\begin{array}{l}100.000 \pm 0 \\
.000^{c}\end{array}$ & $\begin{array}{l}8.333 \pm 1 \\
305\end{array}$ & $\begin{array}{l}4.333 \pm 1 \\
528^{\mathrm{cd}}\end{array}$ & $\begin{array}{l}6.667 \pm 0 . \\
577^{d}\end{array}$ \\
\hline 15.0 & $\begin{array}{l}0.667 \pm 0 \\
577^{\mathrm{abc}}\end{array}$ & $\begin{array}{l}0.667 \pm 0 \\
577 \mathrm{abc}\end{array}$ & $\begin{array}{l}1.000 \pm 0 . \\
000^{\mathrm{abc}}\end{array}$ & $\begin{array}{l}1.333 \pm 0.57 \\
7_{\text {abcd }}\end{array}$ & $\begin{array}{l}100.000 \pm 0 \\
.000^{c}\end{array}$ & $\begin{array}{l}21.200 \pm \\
2.524\end{array}$ & $\begin{array}{l}8.667 \pm 0 . \\
577^{\mathrm{e}}\end{array}$ & $\begin{array}{l}7.333 \pm 1 \\
155^{\mathrm{d}}\end{array}$ \\
\hline 22.5 & $\begin{array}{l}0.333 \pm 0 . \\
577^{\mathrm{ab}}\end{array}$ & $\begin{array}{l}0.333 \pm 0 \\
577^{\mathrm{ab}}\end{array}$ & $\begin{array}{l}2.000 \pm 2 . \\
000^{\mathrm{cd}}\end{array}$ & $\begin{array}{l}2.000 \pm 1.00 \\
0^{\text {cd }}\end{array}$ & $\begin{array}{l}100.000 \pm 0 \\
.000^{c}\end{array}$ & $\begin{array}{l}14.767 \pm \\
1.607\end{array}$ & $\begin{array}{l}5.000 \pm 1 . \\
000^{\mathrm{d}}\end{array}$ & $\begin{array}{l}6.333 \pm 0 . \\
577^{\mathrm{cd}}\end{array}$ \\
\hline
\end{tabular}

Means with the same letter superscript are not significantly different $(\mathrm{P} \geq 0.05)$

Statistical analysis showed significant interactions between clones and NAA on the survivability of the brown stem cuttings. Although, no significant difference $(\mathrm{P} \geq 0.05)$ existed among the NAA concentrations within Clone $I, 15.0 \mathrm{~g} / \mathrm{L}$ and $22.5 \mathrm{~g} / \mathrm{L}$ NAA showed an equal and higher survival rate $(66.667 \%)$ of the brown stem cuttings as compared with the control treatments producing the least rate of $33.333 \%$ (Table $3)$.

Also, no significant difference $(\mathrm{P} \geq 0.05)$ was shown in Clone II among NAA concentrations. However, 7.5, 15.0 and $22.5 \mathrm{~g} / \mathrm{L}$ NAA showed equal and higher brown stem cutting survivability (100.000\%) with the control treatments having lower survival rate of $93.333 \%$ (Table 3 ).

The interaction between clones and NAA on the shoot length of the $H$. brasiliensis brown stem cuttings was statistically different $(\mathrm{P}<0.05)$ (Table 3). In both clones, there was a significant difference $(\mathrm{P}<0.05)$ in the concentration of NAA on the length of shoots of $\mathrm{H}$. brasiliensis brown stem cuttings with $15.0 \mathrm{~g} / \mathrm{L}$ NAA showing the highest shoot length $(9.567 \mathrm{~cm}$ and $21.200 \mathrm{~cm})$ (Table 3). This was followed by $22.5 \mathrm{~g} / \mathrm{L}$ NAA of shoot length whilst the control treatments showing the least shoot length of $2.633 \mathrm{~cm}$ (Table 3 ).

For the number of roots (Fig. 2E) produced, significant difference $(\mathrm{P}<0.05)$ existed in the interaction between the two clones and NAA treated brown stem cuttings with $15.0 \mathrm{~g} / \mathrm{L}$ NAA providing high number of roots $(3.667$ and 8.667). The control treatments had lower number of roots (Table 3). The interaction between the two clones and NAA concentrations showed significance $(\mathrm{P}<0.05)$ in the root length (Fig. 2E) with both $7.5 \mathrm{~g} / \mathrm{L}$ and $15.0 \mathrm{~g} / \mathrm{L}$ NAA producing high mean length of roots of $5.000 \mathrm{~cm}$ and $7.333 \mathrm{~cm}$. The lowest length of shoots was provided by the control treatments (Table 3).

\section{DISCUSSION}

Vegetative propagation provides the best opportunity to ensure the multiplication of valuable trees for production (Mialoundama et al., 2002). A particular importance is the use of stem cuttings which impact significantly on the production of this important economic tree species. The use of stem cutting results in the production of true to type planting materials (clones) with genetic constitution similar to that of the mother plant and thus reliably clone plants with desirable traits (Enslin, 2006). Additionally, the technique leads to early maturity of new plants and the production of large scale planting materials within a short time for field establishment.

\subsection{Effects of clonal types and NAA concentrations on shoot development}

None of the green stem cuttings survived even under the same propagation conditions of the brown stem cuttings. Most of the brown stem cuttings of Hevea sprouted regardless of the concentration of NAA and the type of clones. For the surviving brown stem cuttings, there was significant difference $(\mathrm{P}<0.05)$ between the two clones in the number of roots, length of roots, length of shoots, survival rate and shoot growth. With the large number of both brown and green stem cuttings propagated more than half of them did not survive. Also, of the two clones studied, Clone II had a higher survival rate, number of shoots and roots as well as length of shoots and roots than Clone I. This could be attributed to both biotic and abiotic stresses especially an extremely high temperature and a very low relative humidity during the early stages of planting as well as fungal attacks on the cuttings. The reason for the successful sprouting and growth of brown stem cuttings could be due to the hydrolysis 
and availability of carbohydrates stored within the stem tissues of hardwood cuttings (Leakey, 2004).

Cuttings from green stems because they are slightly lignified and succulent are extremely susceptible to attack by soilborne pathogens (Nestel, 1976). Fungal attack could be a serious threat to the failure and dying of the rubber stem cuttings. Rubber production, as is in the case of other crops is affected by various plant physiological conditions and pathogenic diseases such as South American Leaf Blight (SALB) and Microcyclus ulei (Le Guen et al., 2003).Differences in soil moisture caused by ions such as Sodium, Calcium and Magnesium, aeration; $\mathrm{pH}$ and temperature could affect physical properties, absorption rates, and breakdown of soil as well as plant injury or death (Hartmann and Kester, 1975).

\subsection{Effects of NAA concentrations on sprouting growth, survival rate, length of shoots, length of roots and number of root of $\boldsymbol{H}$. brasiliensisstem cuttings}

The concentrations of NAA had significant influence on length of shoots and roots and the number of roots, except the survival rate and shooting growth of the brown rubber stem cuttings. The treatment of stem cuttings chemically by the application of auxins such as NAA or other growth regulators and fungicides strongly influence the ability of stem cuttings to develop roots. Root initiation and elongation are influenced by genetic, physiological and environmental factors (Leakey, 1985).

It is established that stem cuttings with a single node are better propagules or planting materials for large and successful survival plum. A large sour plum cutting which response to hormone application in small effects could be as a result of high endogenous auxins within the cutting tissues which could have negative interaction with the applied NAA growth regulator (Owuor et al., 2009). Alpha naphthalene acetic acid (ANAA) has been found to be reliable in rooting cuttings (Corpuz, 2013) and there are compounds within stem cuttings such as phenolic that interact with auxins to promote rooting and increase root length (Hartmann et al., 1997).

Root development differs between tree species and among plants within clones. Thus, variation in rooting may be attributed to lack of endogenous auxins, phenolic or other rooting co-factors in the cutting or lack of enzymes or their activators for synthesis of auxin-phenol complexes (Leakey, 1985).

Also, although some showed signs of growth in the early stage, they could not complete the entire planting duration which could be attributed to lack of root to translocate nutrients and moisture through the stem tissues. Some cuttings sprouted vigorously for a long time but later wilted or died due to lack of root formation and rotting of the basal part of the cuttings. Uncontrolled heat and light which cause an increase in temperature may cause plants to suffer from heat injury. Also, insufficient supply of water and drought are detrimental to all plants. Over-supply of water suffocates the plant roots and can cause diseases such as root rot, damping off and collar rot (Enslin, 2006).

Auxins, NAA when applied at high rates to Oxalis plants as a foliar spray was revealed to be phytotoxic (Holt and Chism, 1988). The capacity of the stem cuttings to form roots can be determined by the percentage of cutting rooted, the number of roots per rooted cutting and the speed with which roots emerge and grow (Leakey, 1985).

4.3. Effects of types of clone on sprouting growth, survival rate, length of sprouts, number of roots and length of roots of $\boldsymbol{H}$. brasiliensisstem cuttings

Comparatively, Clone II significantly developed more shoots and roots than Clone I. In addition, the length of sprouts and roots in Clone II was significantly longer than Clone I. The difference in performance between the two clones could be due to the drastic environmental changes which had adverse effect on Clone I than Clone II. The type of clone or genotype of stem cutting under propagation has a great influence on the survival and the growth of plant species. Stem cutting, the most frequent propagation method for woody and herbaceous plants is usually faced with challenging factors resulting from mother plant status/source, media, type of cuttings, plant growth regulators and environmental conditions (Hassanein, 2013). Irrespective of the method of propagation, the rooting percentage of plant species is influenced by different genotypes (clones) (Yang, 2009).

\section{CONCLUSION}

The sprouting and rooting growth success of the Hevea brasiliensis clones, particularly Clone II, out-performed and survived significantly better and higher than Clone $I$ of the brown stem cuttings. Also, there was higher significant $(\mathrm{P}<0.05)$ survival rate of the Hevea brasiliensis brown stem cuttings than the green stem cuttings of which none sprouted. In the case of the levels of NAA influence on the sprouting and rooting growth on the Hevea brasiliensis brown stem cuttings, $15 \mathrm{~g} / \mathrm{L}$ of NAA out-performed better and higher than all the other NAA treatments and the control treatments. The interaction effects between Clone II and $15.0 \mathrm{~g} / \mathrm{L}$ NAA levels statistically $(\mathrm{P}<0.05)$ performed higher and better than the 
other interactions. Therefore, an alternative method to ensure rapid and mass propagation of Hevea brasiliensis planting materials for plantation is established. In using stem cuttings for the propagation of Hevea brasiliensis trees, these findings can be considered to shape the propagation procedures.

Propagation methods such as marcottage which can promote effective rooting on stem cuttings could be tried.The growth medium (soil), fungicide, season and timefor the collection and propagation of Hevea brasiliensis stem cuttings must be taken into consideration since they influence survivability and growth.

\section{ACKNOWLEDGEMENTS}

The authors are most appreciative to the late Elder Charles Kofi Hayford who supported and sponsored this research.Also, we are grateful to Dr. Harry Amoatey and Prof. Kenneth E. Danso and all the scientists and technicians of Biotechnology and Nuclear Agriculture Research Institute of Ghana Atomic Energy Commission for an unrestricted accessibility to their resources.

\section{REFERENCES}

[1] Corpuz, O. S. (2013). Stem cut: An alternative propagation technology for rubber (Hevea brasiliensis) tree species. International Journal of Biodiversity and Conservation, 5:2:78-87.

[2] Das, P., Basak, U. C., \&Das, A. B. (1997). Metabolic changes during rooting in pre-girdled stem cuttings and air-layers of Heritiera. Botanical Bulletin of Academia Sinica (Taipei), 38: 91-95.

[3] Enslin, B. (2006). Plant Propagation. Learner Guide Primary Agriculture.

[4] Fowler, J. (2010). General Information on Propagation by Stem Cuttings.University of California, Agriculture and Natural Resources, Cooperative Extension - Yolo County, 70 Cottonwood Street, Woodland, CA 95695: 1-3.

[5] Hartmann, H. T., Kester, D. E., Davis, F. T., \& Geneve, R. L. (1997). Plant Propagation: Principles and Practices (6th ed.). New Jersey, USA: 770.

[6] Hartmann, H. T., \& Kester, D. E. (1975). Plant propagation: Principles and Practices (3rd ed.). Prentice-Hall, Inc., Englewood Cliffs, New Jersey.

[7] Hassanein, A. M. A. (2013). Factors Influencing Plant Propagation Efficiency via Stem Cuttings. Journal of Horticultural Science \& Ornamental Plants, 5:3: 171176.

[8] Holt, J., \& Chism, W. (1988). Herbicidal activity of NAA (naphthaleneacetic acid) on creeping woodsorrel
(Oxalis corniculata) in ornamentals. Weed Science, 36: 227-233.

[9] Le Guen, V., Lespinasse, D., Oliver, G., Rodier Goud, M., Pinard, F., \& Seguin, M. (2003). Molecular mapping of genes conferring field resistance to South American Leaf Blight (Microcyclus ulei) in rubber tree. Theoretical and applied genetics, 108:1: 160-167.

[10]Leakey, R. R. B. (2004). Physiology of Vegetative Reproduction. Encyclopedia of Forest Sciences. Agroforestry and Novel Crops Unit. School of Tropical Biology, James Cook University, Australia.

[11]Leakey, R. R. B. (1985). The capacity for vegetative propagation in trees. In: Cannell, M.G.R.; Jackson, J.E., (eds.). Attributes of trees as crop plants. Abbotts Ripton, Institute of Terrestrial Ecology: 110-133.

[12] Mialoundama, F., Avana, M., Youmbi, E., Mampouyl, P., Kopguep, F., Tsobeng, A. C., \& Abega, J. (2002). Vegetative propagation of Dcrodesedulis (G. Don) H.J Lam by marcots, cuttings and micropropagation. Forests Trees Livelihoods, 12: 85-96.

[13] Nestel, B. (1976). African cassava mosaic: report of an interdisciplinary workshop, Muguga, Kenya, 19-22 February, 1976, IDRC-071e: 48.

[14] Owuor, B., Musyimi, D., Ocaidoand, M., \& Asimwe, J. (2009). Vegetative propagation of the large sour plum (Ximenia caffra Sond) by rooting of pleiotropic stem cutting. . ARPN Journal of Agriculturaland Biological Science, 4: 11-67

[15] Palanisamy, K., \& Subramanian, K. (2000). Vegetative Propagation of Mature Teak Trees (Tectona grandis L.): $1-59$.

[16] Satchuthananthavale, R. (1973). Hevea Tissue Culture. Q. J1. Jlubb. Ties. Institute of Sri Lanka (Ceylon), 50: 91-97.

[17] Yang, Z. (2009). Vegetative Propagation and Genetic Fingerprinting of Eucalyptus grandis and Eucalyptus amplifolia. A Thesis Presented to the Graduate School of the University of Florida in Partial Fulfillment of the Requirements for the Degree of Master of Science University of Florida. 